\title{
Teori Kepemimpinan Situasional 3-D
}

\author{
Burhanudin Mukhamad Faturahman \\ Pusat Penelitian Badan Keahlian DPR RI \\ burhanmfatur@gmail.com
}

\begin{abstract}
The leader is the most dominant figure on the effectiveness of achieving organizational goals. But on the other hand subordinates also have an important role so that leaders are able to achieve goals effectively by prioritizing collectivity. Leaders in their role in influencing subordinates are inseparable from their skills in positioning themselves in certain situations. Therefore, Reddin revealed that the situational dimension becomes important to consider, namely on the task dimension, relationship orientation and effectiveness. Furthermore, Reddin developed the three dimensions into 12 types of leaders through four basic types of leaders namely separated types, related types, dedicated types and integrated types. Each type is grouped into 8 types of leaders from less effective to more effective. The implications of Reddin's theory make it easy for leaders in achieving organizational goals that emphasize situational relationships with subordinates.
\end{abstract}

Keywords: 3D theory, task, relationships, effectiveness.

\section{Pendahuluan}

Teori kepemimpnan menunjukkan tahap yang bervariasi diantara pengembangan pemimpin dan bawahan di lingkungan yang terkontrol dengan berbagai variabel situasi yang krusial untuk level kesiapan bawahan. Seorang pemimpin harus bisa secara efektif mengarahkan berbagai variabel situasi sementara, diperlukan ketabahan dalam merawat tujuan secara tepat. Dengan demikian mereka memiliki kebiasaan menggunakan pengaruh non-koersif untuk memandu anggota kerja menuju tujuan bersama dan tujuan umum organisasi.

Pemimpin sering mempercepat bawahan terkait persoaniltas yaitu kepemilikan dan tanggungjawab dari layanan tertentu yang mereka mampu membantunya. Disinilah kepemimpinan mulai memberikan tekanan agar lebih efektif dan dituntut lebih mampu mendorong bawahan menemukan 
pekerjaan mereka sebagai kebutuhan mereka sendiri. karena itulah banyak para pemimpin mengevaluasi keahlian dan kemampuan meraka agar para pekerja lebih bisa memotivasi diri mereka sendiri.

Studi dari kepemimpinan lebih didominasi pada literatur manajemen dan perilaku organisasi. Review dari para peneliti terpelajar memberikan gambaran dari sifat individu, perilaku, pola interaksi, peran mitra, persepsi pengikut, mempengaruhi pengikut, mempengaruhi tujuan, dan mempengaruhi budaya organisasi secara keseluruhan. Pendekatan kepemimpinan ini mengindikasikan kelemahan secara konseptual dan keluar dari kenyataan empiris (Yuki, 1989: 87). Meskipun dalam memahami kepemimpinan telah keluar, kemajuan telah dibuat pada studi kepemimpinan sifat, perilaku, kekuasaan dan faktor situasional. Artinya, kepemimpinan dihadapkan pada banyak tanggungjawab diantara kekuasaan, pengaruh dan perilaku yang digunakan secara tepat dan berkelanjutan, belum lagi dalam jangka pendek.

\section{Studi pada Universitas}

OHIO University. Universitas ini mengindikasikan studi yang mengarah pada perilaku pemimpin. OHIO fokus pada perilaku kepemimpinan yang mana studi tersebut berkontribusi terhadap perilaku kepemimpinan sebagai acuan pada struktur (structure) dan pertimbangan (consideration). Terdapat empat kuadran dalam inisiasi struktur dan pertimbangan.

Gambar 1. Kuadran OHIO

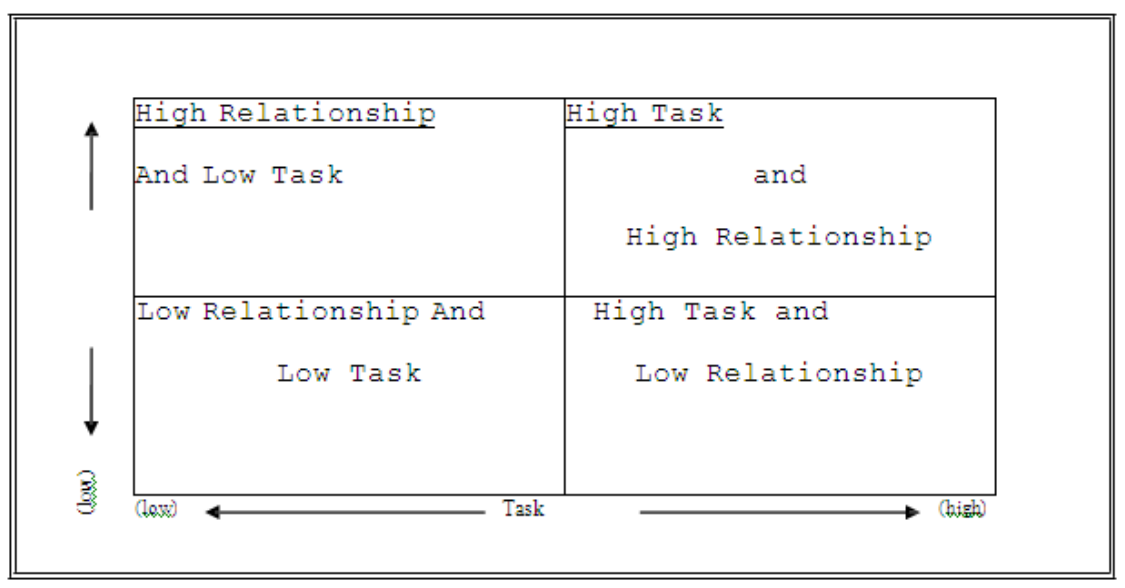

Sumber: Bates (2015)

Diagram tersebut dikembangkan dalam rangka menyajikan dua dimensi yang independen dari kepemimpinan. Inisiasi struktur direncanakan dengan 
baik dalam kerja organisasi yang dapat diselesaikan dengan baik, termasuk merawat standar kinerja, ketepatan penyelesaian waktu kerja, dan pertemuan batas waktu (deadline). Seorang pemimpin memutuskan secara eksplisit setiap detail kebutuhan yang harus diselesaikan. Maka dari itu, dukungan pemimpin dilakukan dengan menekankan rantai komando secara langsung terhadap definisi dan strukturisasi dari bawahan (Reddin, 1970).

Pertimbangan dikonsentrasikan dengan merawat dan menekankan pada hubungan (relationship). Faktor ini mendeskripsikan kesejahteraan para anggota kelompok termasuk mengekspresikan apresiasi kerja yang baik, kepuasan kerja, menguatkan dan merawat kesamaan antar bawahan, membuat perasaan bawahan yang spesial, pendekatan yang lebih mudah, memberikan saran terhadap pelaksanaan, memperoleh persetujuan terhadap permasalahan yang penting. Pemimpin ini fokus pada membangun hubungan (relationship), menekankan pertemanan, membangun kepercayaan dan keharmonisan interpersonal (Bass \& Stodgill, 1990).

Michigan university. Studi universitas ini mengarah pada dua konsep yaitu gaya kepemimpinan berpusat pada karyawan dan gaya kepemimpinan berpusat pada pekerjaan. Pemimpin yang berpusat pada karyawan selalu mengarah pada aspek hubungan pada pekerjaan mereka. Tipe ini menekankan pada pentingnya hubungan dengan efektivitas pekerjaan (Reddin, 1967). Mereka percaya bahwa untuk menarik perhatian seseorang penting untuk memberikan penghargaan secara individualitas dan kebutuhan personal. Pimpinan berpusat pada pekerjaan menekankan pada produksi dan aspek teknis pekerjaan yang cenderung berhubungan dengan orientasi tugas dan keahlian teknis dengan efektivitas pekerjaan, disini karyawan sebagai alat untuk memenuhi tujuan organisasi.

Kesimpulan studi ini: 1) pemimpin yang efektif cenderung mendukung dan memuaskan karyawan, 2) mereka mengadopsi metode supervisi dan strategi, 3) mereka cenderung berorientasi pada tujuan. Berdasarkan studi ini pertimbangan variabel situasional tidak ada. Tidak ada yang menunjukkan perilaku pemimpin berubah berdasarkan situasi yang berbeda (Hersey et al., 2001). Teori perilaku menggunakan perilaku pemimpin sebagai variabel dependen dan mempelajari hubungan dengan 
efektivitas organisasi dan kepuasan kerja. Masalah umum studi OHIO dan Michigan adalah kurangnya studi berdasarkan faktor situasional. Kepemimpinan yang efektif mangambil situasi tertentu atau lingkungan tertentu, oleh karenanya variabel situasional perlu dipertimbangkan. Kepemimpinan situasional muncul tahun 1960an karena kelemahan metodologi teori perilaku.

\section{Teori Gaya Manajemen 3-D}

Reddin (1970) mengembangkan teori efektivitas kepemimpinan 3 dimensi (3D) pada dua elemen sentral dari perilaku kepemimpinan OHIO. Dia mengembangkan empat tipe gaya dari dua elemen kerja (task) dan hubungan (relationship). Esensi dari teori 3D adalah dua elemen utama dari perilaku pemimpin untuk menyelesaikan tugas dan hubungan dengan orang-orang yang menyelesaikan tugas tersebut. Aspek tambahan teori 3D adalah 1) gaya terpisah 2) gaya dedikasi 3) gaya keterkaitan dan 4) gaya integrasi.

Gaya terpisah terdiri dari kerja rendah dan orientasi hubungan rendah. Dengan demikian, ini terpisah baik orientasi tugas dan orientasi hubungan. Gaya dedikasi yaitu pemimpin menggunakan orientasi tugas yang tinggi tapi orientasi hubungan rendah. Gaya keterkaitan menggunakan orientasi hubungan tinggi dan orientasi tugas rendah. Dan gaya integrasi mengkombinasikan orientasi kerja tinggi dan hubungan tinggi. Berdasarkan Reddin (1967) baik tugas maupun hubungan dapat dipertimbangkan efektif atau tidak efektif sampai tiga dimensi, yang mana permintaan perilaku berdasarkan situasi ditambahkan.

Efektivitas pemimpin ditentukan dengan ketepatan kerja dan orientasi hubungan dari pemimpin pada permintaan situasi. Dari sini pemimpin menunjukkan bahwa tidak ada tugas dan orientasi hubungan yang efektif jika tidak memenuhi situasi yang sebernarnya. Ini sejalan dengan empat tipe yang diidentifikasi. Masing-masing gaya dapat efektif dan tidak efektif tergantung pada situasi. Hasilnya, Reddin meluaskan jangkauannya dari empat tipe dasar ke 12 dengan menambahkan empat tugas dan perilaku hubungan yang kurang efektif dan empat tipe yang dipertimbangkan sebagai pemimpin yang efektif berdasarkan ketepatan situasi (Reddin, 1970). Menurutnya, pemimpin yang efektif bisa mengetahui bagaimana membaca situasi. Situasi terdiri dari lima faktor yang tidak berdiri sendiri; elemen inklusif organisasi, informasi, teknologi, bawahan dan atasan. Pemimpin adalah satu bagian dengan situasi itu sendiri 
sehingga ketepatan perilaku pemimpin pada permintaan situasi menentukan efektifitas dari pemimpin baik tugas dan hubungan. Teori 3D ini dipertimbangkan sebagai teori situasional yang fokus pada pemimpin maupun pengikut. Life Cycle Theory of Leadership dari Hersey, dkk (1969) merupakan pengembangan lanjutan dari teori 3D Reddin yang mana teori 3D meletakkan fondasi berupa klasifikasi perilaku manajer di dua variabel (orientasi tugas dan orientasi hubungan). Orientasi tugas dilakukan secara langsung pada bawahan untuk pencapaian tujuan dan orientasi hubungan didefinisikan sebagai penekanan hubungan yakni rasa percaya, menghargai dan perimbangan ide dan perasaan antara pimpinan dan bawahan (Cote,2017).

Pada dasarnya mengetahui gaya kepemimpinan ini membantu kita untuk adopsi berbagai situasi. Meskipun ada yang menggunakan kepemimpinan tertentu namun tidak selalu digunakan. Pergantian antara gaya kepemimpinan membutuhkan situasi manajemen untuk mencapai kesuksesan. Setelah empat tipe dasar gaya kepemimpinan lebih lanjut Reddin mengukur efektifitas dari masing-masing gaya yang dikembangkan kedalam 8 gaya kepemimpinan.

Tabel 1. Gaya Kepemimpinan kurang efektif dan lebih efektif pada tipe dasar

Sumber: Reddin (2011)

\begin{tabular}{|l|l|l|}
\hline Less Effective & Basic types & More Effective \\
\hline Deserter & SEPARATED & Bureaucratic \\
\hline Missionary & RELATED & Developer \\
\hline Autocratic & DEDICATED & Benevolent Autocratic \\
\hline Compromiser & INTEGRATED & Executive \\
\hline
\end{tabular}

\section{Tipe dasar terpisah (separated).}

a. Deserter: Gaya kepemimpinan kurang efektif. Seseorang yang tidak sama sekali atau hanya sedikit memiliki ketiga orientasi (tugas, orientasi hubungan, efektifitas).

The Deserter kurang menunjukkan perhatian baik pada tugas maupun kepada pergaulan. Dia tidak atau kurang efektif,bukan saja karena kurang perhatian, melainkan juga karena pengaruh negatifnya terhadap semangat kerja. Dia tidak hanya secara aktif menjauhi tugas pekerjaan tetapi juga aktif menghalangi keberhasilan pekerjaan orang lain dengan mencampuri atau menahan segala informasi. Tipe Deserter sering terdapat pada organisasi-organisasi besar. Dia 
merasakan dirinya diperlakukan tidak pantas/tidak adil, sehingga ia memutuskan untuk mengabaikan organisasi, atau jika sempat ia akan merusak organisasi dari dalam. Kadang- kadang tipe ini bisa menghambat dengan berbagai kelicikan secara penuh kelihaian, sehingga hanya pengamat dekatlah yang bisa mengetahui, apa yang sedang dikerjakan.

Dalam bentuk yang paling agresif dan negatif orang ini mencuri sesuatu dari organisasi. Dalam bentuk yang paling halus, nampaknya seperti menentang perubahan namun jika menyetujuinya kemudian secara diam-diam melakukan sabotase, membuat kesulitan di segala bidang yang menurunkan hasil kerja, menghasut orang lain yang menyebabkan akibat buruk pada moral pegawai. Tipe Deserter yang licik menghasilkan sesuatu hanya sekedar untuk menutup kecurigaan orang lain terhadap keberadaannya. Dia tetap tidak melibatkan diri dalam segala kegiatan, bilamana dia seorang pemimpin dia senang sekali mengirimkan setiap masalah kepada panitia untuk membebaskan dirinya dari tanggung jawab yang bagaimanapun kecilnya.

Seseorang dibuat menjadi Deserter oleh kekeliruan yang besar dari atasannya. Karena pada umumnya orang tidak akan menyelonong memasuki suatu organisasi dengan membawa tingkat seperti itu. Mereka didorong masuk ke dalam tipe ini oleh atasan dan lingkungan dimana dia berada.

b. Bureaucratic: gaya kepemimpinan lebih efektif (seseorang yang hanya mempunyai sifat efektif saja dengan orientasi tugas yang rendah).

The Bureaucratic. Hampir sama dengan Deserter, dia tidak sungguhsungguh menaruh minat pada tugas (TO) atau pergaulan (RO). Dia sendiri bagaimanapun juga efektif karena amat patuh kepada peraturan. Ia memelihara suasana kepatuhan tersebut tetapi secara pribadi kurang menghayati dan melibatkan di dalam permasalahannya. Orang Birokrat memandang dirinya sebagai seorang yang paling efisien. Dia mentaati peraturan organisasi, menempuh jalan yang telah digariskan. Ia adalah seseorang yang berpegang teguh kepada hal-hal mendetail serta orientasi utamanya adalah "aturan 
permainan". Baginya hanya peraturan yang ada dan berlaku serta pengalaman dimasa lampau itulah petunjuk yang harus dipatuhi dan diikuti.

Golongan Birokrat ini biasanya tumbuh dalam lingkungan dinas pemerintahan. Dia seringkali terdapat pada organisasi yang prestasinya kadang-kadang sukar diukur/dinilai. Tipe ini sangat efektif dalam hal kepatuhan terhadap peraturan tetapi dari golongan Birokrat ini sukar didorong pada peningkatan produksi dan tidak mau mengembangkan bawahannya. Dia berpendapat bahwa pergaulan yang sehat dan matang sukar dicapai dan perencanaan jangka panjang itu adalah gagasan kurang baik. Dia sangat terikat pada apa yang terjadi di masa lalu dalam organisasinya.

\section{Tipe dasar keterkaitan (related).}

a. Missionary. Gaya kepemimpinan kurang efektif (seseorang yang hanya mempunyai orientasi kepada hubungan saja dengan orientasi tugas yang rendah).

Missionary adalah seseorang yang suka berbaik budi, ramah tamah dan menempatkan pergaulan hidup di atas segalanya. Golongan ini kurang efektif karena niatnya hanya menjadi "orang baik" yang justru merupakan hambatan baginya untuk mengambil risiko. Gaya kepemimpinannya tidak efektif oleh karena dia tidak pernah menyelesaikan sesuatu permasalahan. Dia senantiasa menghindari bentrokan dan memilih kebijaksanaan dengan lebih baik memindahkan atau memberikan promosi atau kenaikan upah kepada orang-orang yang suka membuat kesulitan. Dia mau merubah-rubah pendirian demi memelihara kedamaian. Yang paling buruk menurut pendapatnya adalah melakukan sesuatu yang selalu harus menghasilkan yang terbaik.

b. Developer. gaya kepemimpinan lebih efektif (seseorang yang mempunyai keefektifan dengan orientasi hubungan yang tinggi dan orientasi tugas yang rendah).

The Developer, adalah seseorang yang senantiasa menempatkan kepercayaan kepada orang lain. Dalam beberapa hal merupakan kepenakan golongan Missionary tetapi lebih efektif dengan memberikan motivasi pada orang lain. Dia memandang bahwa tugasnya yang utama adalah mengembangkan bakat orang lain. Di kebanyakan organisasi golongan ini 
tidak begitu nampak secara menonjol. Dia hanya duduk bekerja merubah seorang "ahli teknik" menjadi seorang "general manager" (pemimpin) dan tidak seorangpun mengetahuinya sampai dia meninggalkan jabatannya.

Tugas pekerjaannya dipandang orang lain sangat menyenangkan karena biasanya luas pergaulan dan bekerjasamanya dengan dia. Keahlian untuk menciptakan kondisi “memajukan orang lain" itu kadangkadang berlaku tanpa ada yang mengetahuinya. Golongan developer mempunyai asumsi yang mengasyikkan mengenai pekerjaan. Dia berpendapat bahwa "bekerja" adalah "wajar" dan sewajar seperti kebutuhan manusia untuk "beristirahat" atau "bermain". Dia percaya bahwa manusia mau berlatih untuk "berjalan sendiri", "mengendalikan diri sendiri" serta mencapai tingkat rasa tanggung jawab yang tinggi. Dia percaya pada apa yang sukar diyakini oleh kebanyakan manajer, yaitu bahwa intelegensia, imajinasi dan kreativitas tersebar luas pada semua orang dan bukan hanya terdapat jabatannya pada para pemimpin saja.

\section{Tipe dasar dedikasi (dedicated)}

a. Autokratik. Gaya kepemimpinan kurang efektif (seseorang yang mempunyai orientasi tugas saja, sedang orientasi lainnya rendah).

The Autocrat, merupakan tipe seseorang yang menempatkan tugas di atas segala-galanya. Dia kurang efektif karena kurang mengacuhkan pergaulan, dan kurang mempercayai orang lain. Banyak yang takut kepadanya dan kurang disenangi sehingga orang hanya mau bekerja bila dia menggunakan tekanan kekerasan saja.

Tokoh Autocrat ini beranggapan bahwa manusia pada umumnya sama saja, yaitu kurang senang bekerja dan menghindarkan pekerjaan jika mungkin. Oleh sebab itu kebanyakan orang harus dikontrol, diperintah dan jika perlu diancam dengan hukuman agar dia bekerja seperti yang diinginkannya.

Tipe ini beranggapan pada umumnya orang-orang lebih suka diperintah, menghindari tanggung jawab dan secara relatif kurang bersemangat kerja dan suka mencari "selamat" di atas segalagalanya.Golongan Autocrat memandang para pekerja sebagai bagian dari mesin. Anak buah 
tugasnya hanya melaksanakan perintah.

b. Autokratik bijak.

Gaya kepemimpinan lebih efektif (seseorang yang mempunyai keefektifan dengan orientasi tugas cukup tinggi sedang orientasi hubungan yang rendah.

The Benevolent Autocrat, mengembangkan sekelumit kepercayaan pada metode dan prosedur yang sehat tentang apa yang harus dikerjakan. Dia berkepentingan dengan dan efektif dalam memperoleh hasil. Keahliannya yang utama adalah memerintah orang lain melakukan apa yang dia kehendaki, tanda menciptakan perasaan kecil hati pada orang itu untuk melakukannya. Dia memiliki perasaan orientasi dengan golongan Autocrat, walaupun dia lebih halus dan lebih efektif.

c. Gaya ini sangat terkenal di lingkungan industri dewasa ini. Dia seringkali mencerminkan kepemimpinan yang baik dan berusaha meningkatkan keahlian dengan cara belajar dari kesalahan-kesalahannya.

Golongan Benevolent Autocrat biasanya punya ambisi, mengetahui sangat baik peraturan serta metode organisasi. Ketika sampai pada puncak jabatan dengan produksi yang tinggi, dia tidak tahu lagi bagaimana yang sebaiknya bergaul dengan bawahannya. Dia sepenuhnya mau terlibat, namun tidak demikian halnya bawahan yang bekerja dengan dia.

\section{Tipe dasar integrasi (integrated)}

a. Kompromi. Gaya kepemimpinan kurang efektif (seseorang yang kurang efektif tetapi mempunyai orientasi tugas dan orientasi hubungan yang memadai).

The Compromiser, mengakui manfaat orientasi tugas (TO) dan orientasi pergaulan (RO) tetapi tidak mampu untuk mempersatukan orientasi ini menjadi keputusan yang sehat. Sikap kompromi dan mendua hati merupakan ciri khasnya.

Pengaruh kuat terhadap keputusannya adalah berupa "tekanan-tekanan berat" dari kiri dan kanan. Dia berusaha mengurangi permasalahan yang timbul daripada meningkatkan produksi dalam jangka panjang. Dia berusaha sedapat mungkin membuat orangorang yang mempengaruhi kariernya 
senang kepadanya. Golongan Compromiser sebagaimana namanya tidak pernah mengerjakan segala sesuatu dengan tuntas. Dia mendorong tetapi tidak sungguhsungguh.

$\begin{array}{lrr}\text { Sementara dia } & \text { tidak } \\ \text { mentoleransikan prestasi } & \text { yang } \\ \text { merosot, namun dia } & \text { tidak } \\ \text { mengharapkan prestasi } & \text { tinggi. }\end{array}$

Semua ini mengabadikan ketidak efektifannya. Golongan Compromiser berkeyakinan bahwa produksi yang optimum itu hanya impian belaka. Dia beranggapan bahwa setiap rencana harus merupakan serangkaian kompromi. Dia hanya memandang bahwa yang dapat dikerjakan kerjakanlah itu saja. Dia mau hidup dan membiarkan pula orang lain hidup. Jika nampaknya sesuatu akan berjalan, dia akan memberikan dukungan.

b. Eksekutif. Tipe gaya kepemimpinan lebih efektif (seseorang yang mempunyai ketiga orientasi tersebut: tugas, orientasi hubungan, efektifitas)

The Executive, adalah gaya kepemimpinan yang merupakan contoh dari "manajer yang sangat efektif". Ia adalah seorang yang memandang pekerjaannya membuat bawahannya dapat mengerjakan halhal yang paling baik. Dia menggariskan standard dan prestasi yang tinggi, tetapi dia tahu bahwa dia harus memperlakukan masingmasing orang berlainan. Dia efektif, dalam hal kepatuhannya terhadap tugas dan pergaulan sangat meyakinkan semua orang dan merupakan suri tauladan bagi semuanya.

Golongan Executive menyadari hal itu dan bekerja untuk menghasilkan yang efektif yang berjalan lancar, dia menciptakan iklim yang memberikan pengaruh segar pada kelompok untuk bergerak ke arah tujuan bersama. Dia menggugah partisipasi dan dengan itu menumbuhkan rasa keterkaitan bawahannya. Ia membangkitkan rasa keterlibatan dalam merencanakan dan dengan itu dia memperoleh hasil pemikiran yang terbaik dari semuanya. Dia mengetahui bahwa setiap orang yang matang dan dewasa "memerlukan dua-duanya kebebasan dan keterikatan". Dia memahami bahwa keperluan individual dan tujuan organisasi suatu tim untuk mencapai konsensus bersama. Golongan Executive menerima 
ketidaksepakatan dan perbedaan pendapat mengenai salah satu tugas.

Dia memandang sikap yang demikian sebagai suatu yang diperlukan, normal dan pada tempatnya. Dia tidak menekan, memalingkan muka atau menghindari persengketaan. Dia berpendapat bahwa semua perbedaan dapat disatukan dan perselisihan dapat diselesaikan dan bilamana hal ini tercapai, hasilnya merupakan kata sepakat yang mengikat. Dia tidak punya seorang "penggemblengan" semangat melainkan tim kerjanya memiliki pengalaman dan persatuan yang kuat dengan semangat yang tinggi. Dia tidak "mengiming-imingi" tetapi bawahannya bekerja keras, dia tidak mau melempar kesalahan kepada keputusan bersama (tim), tetapi semua anggota tim masing-masing akan merasakan dengan sendirinya keterlibatan dirinya baik dalam kegagalan maupun dalam keberhasilan. Berikut disajikan tabel poin penting dalam efektivitas pemimpin.

Tabel 2. Efektifitas 8 Tipe Pemimpin

\begin{tabular}{|c|c|c|c|}
\hline \multicolumn{4}{|c|}{ KURANG EFEKTIF } \\
\hline DESERTER & MISSIONARY & AUTOCRAT & COMPROMISER \\
\hline $\begin{array}{l}\text { Tidak ada rasa } \\
\text { keterlibatan }\end{array}$ & $\circ$ Santai & Kaku & Angin-anginan \\
\hline - Semangat rendah & $\circ$ Penolong & Diktator & Diktator \\
\hline - Sukar diramalkan & - Lemah & Keras Kepala & Berpandangan pendek \\
\hline
\end{tabular}

\begin{tabular}{|c|c|c|c|c|}
\hline \multicolumn{5}{|c|}{ LEBIH EFEKTIF } \\
\hline BUREAUCRAT & DEVELOPER & BENEVOLENT & & EXECUTIVE \\
\hline $\begin{array}{l}\text { Patuh pada } \\
\text { peraturan }\end{array}$ & $\begin{array}{l}\text { Menciptakan } \\
\text { kerjasama }\end{array}$ & $\begin{array}{l}\text { Mampu } \\
\text { memotivasi orang } \\
\text { lain }\end{array}$ & $\circ$ & $\begin{array}{l}\text { Berorientasi ke } \\
\text { masa depan }\end{array}$ \\
\hline - Loyal & - Menggunakan & $\begin{array}{l}\text { Belajar dari } \\
\text { pengalaman }\end{array}$ & $\circ$ & $\begin{array}{l}\text { Membangkitkan } \\
\text { partisipasi } \\
\text { bawahan }\end{array}$ \\
\hline $\begin{array}{l}\text { - Memelihara } \\
\text { lingkungan }\end{array}$ & $\begin{array}{l}\text { - Percaya pada } \\
\text { orang lain }\end{array}$ & $\begin{array}{l}\text { Efektif untuk } \\
\text { memperoleh hasil }\end{array}$ & $\circ$ & $\begin{array}{l}\text { Berpandangan } \\
\text { jangka panjang }\end{array}$ \\
\hline & $\begin{array}{l}\text { Mengembangka } \\
\mathrm{n} \text { bakat orang } \\
\text { lain }\end{array}$ & $\begin{array}{l}\text { - Paham aturan dan } \\
\text { metode kerja }\end{array}$ & $\circ$ & $\begin{array}{l}\text { Memotivasi } \\
\text { dengan baik } \\
\text { Bekerja efektif }\end{array}$ \\
\hline
\end{tabular}


Sumber: LAN (2008)

Selanjutnya model dari Reddin dimodikasi dari tipe kepemimpinan yang kurang efektif hingga tipe kepemimpinan yang lebih efektif.

\section{Gambar 2. Modifikasi Model Teori 3D Efektifitas Manajerial Reddin}

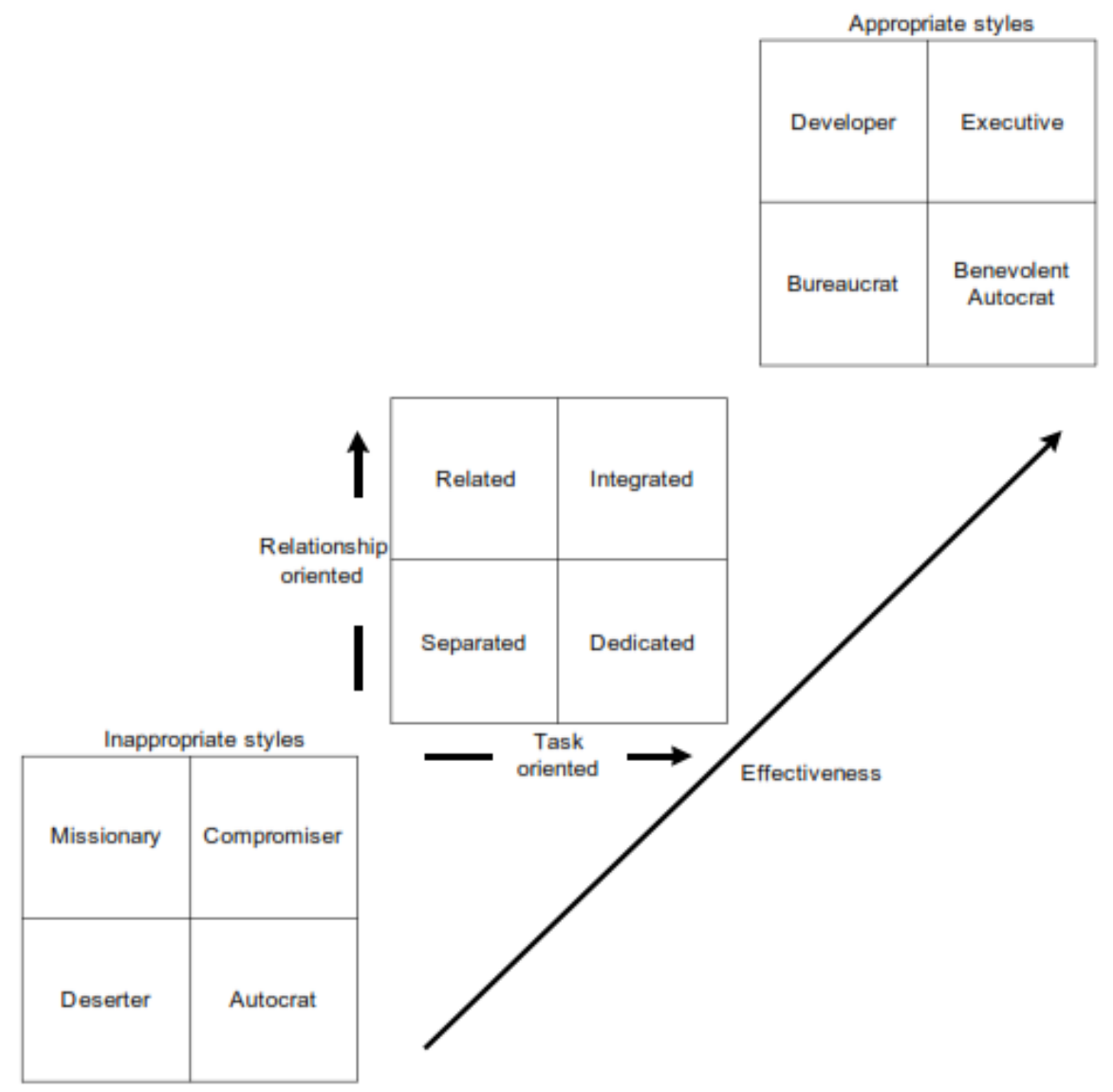

Sumber: Reddin (1970)

Beberapa istilah digunakan perilaku kerja untuk merepresentasikan inisiasi dimensi struktur dan perilaku hubungan agar menjadi pertimbangan. Empat kuadran merepresentasikan satu dari empat gaya kepemimpinan. Masingmasing gaya kepemimpinan mendeskribsikan pola perilaku bahwa orang akan menggunakan ketika bermaksud untuk mempengaruhi pihak lainnya. empat dasar gaya kepemimpinan diberi label tugas tinggi dan hubungan tinggi, tugas tinggi dan hubungan rendah, tugas rendah dan hubungan tinggi dan terakhir tugas rendah dan hubungan rendah.

Kesimpulan dan Implikasinya Terhadap Pemimpin

Untuk mengadopsi gaya yang sesuai, seorang pemimpin tidak hanya memahami beberapa pemikiran yang terus berkembang tentang gaya saja, 
tetapi ia juga harus mempunyai kepekaan atas situasi yang dihadapi. Diantara persyaratan yang dimiliki oleh pemimpin yang peka atas situasi antara lain:

1. Menyadari bahwa manusia adalah makhluk yang sangat kompleks, dimana tidak ada gaya yang paling baik untuk semua orang dan tidak ada gaya yang sama afektis atas orang yang satu dan orang lain.

2. Mau menghargai pikiran dan pendapat orang lain. Dapat mendengarkan dengan baik. Mau mengerti terlebih dahulu sebelum berupaya untuk dimengerti.

3. Tidak emosional, dapat mengungkapkan pikiran dan perasaan pada saat yang sesuai.

4. Menghindari gaya komunikasi yang kaku.

5. Dapat mengendalikan rasa tertekan.

Sikap kaku artinya seperti ungkapan "masa bodoh dengan situasi, pokoknya..." serta sikap tanpa prinsip, artinya selalu berupaya memenuhi harapan setiap orang, akan menjadikan seorang pemimpin gagal mengadopsi gaya kepemimpinan yang sesuai. Disamping itu juga akan menjadikan seorang pemimpin gagal menjadi pendengar yang baik. Padahal daya sembuh daripada telinga yang peka mendengarkan sangat tinggi dalam menyelesaikan masalah organisasi dan masyarakat. Kemampuan mendengarkan yang baik akan memperbaiki hubungan antar sesama, menghasilkan respek orang lain terhadap kita.

\section{Daftar Pustaka}

Bates, C. (2015). History of Organizational Theory. International Journal of Management. Volume 3, Issue 10 (13-24)

Cote, R. (2017). A Comparison of Leadership Theories in an Organizational Environment . International Journal of Business Administration Vol. 8, No. 5 (2835)

Lembaga Administrasi Negara. (2008). Kepemimpinan dalam organisasi, Modul Pendidikan Dan Pelatihan Kepemimpinan Tingkat III. Jakarta, LAN

Reddin, W. J. (1970). Managerial Effectiveness. McGraw Hill: New York.

Reddin, W.J. (2011). Reddin's 3-D Leadership model. Diakses dari http://www.reddinconsultants.c om/wp- 
Jurnal Politik dan Sosial Kemasyarakatan

Vol 11 No 3 (2019) : Desember 2019

content/uploads/2011/05/engli

d_leadership_model_def.pdf pada 3

sh_reference_reddin-s_3-

Desember

2018 